International Journal on Applied Bioengineering, Vol.3, No.1, January 2009

\title{
JATROPHA BIODIESEL DEVELOPMENT AND CHARACTERIZATION FOR USE AS A FUEL IN COMPRESSION IGNITION ENGINES
}

\author{
P Manjula. ${ }^{1}, \mathrm{~N}$ Manoharan. ${ }^{2}$, E Palanisamy. ${ }^{3}$ R Kannappan. ${ }^{4}$ \\ ${ }^{1,3}$ Research Scholar, Sathyabama University, Chennai, India, '²Dean (PG Studies \& Research), Sathyabama University, Chennai, India \\ ${ }^{4}$ Principal, Sri Sai Ram Engineering College, Chennai, India \\ E-mail: manju_16_2000@yahoo.com
}

\section{ABSTRACT}

Neat vegeTable- oils pose some problems when subjected to prolonged usage in $\mathrm{Cl}$ engine. The increasing industrialization and motorization of the world has led to a steep rise for the demand of petroleum based fuels. Petroleum based fuels are obtained from limited serves. These problems are reduced to minimum by subjecting the vegeTable- oils to the process of transesterification called Jatropha biodiesel. The important properties of Jatropha biodiesel thus developed are evaluated and compared in relation to that of conventional diesel oil. This paper touches upon well-to wheel greenhouse gas emissions, well-to-wheel efficiencies, fuel versatility, infrastructure, availability, economics, engine performance and emissions, effect on wear, lubricating oil etc. Diesel, Jatropha oil and Jatropha biodiesel are used as fuels in the $\mathrm{Cl}$ engine and the performance and emission characteristics of the engine are analyzed. The data generated for various concentrations of biodiesel blends were compared with baseline data generated for neat diesel oil. Tests were carried out over entire range of engine operation at varying condition of speed and load. It was found that $20 \%$ blend of biodiesel gave the best performance amongst all blends. The experimental results proved that the use of biodiesel in compression ignition engines is alternative to diesel.

KEYWORDS: Biodiesel, Esterification, Diesel, Jatropha, Petroleum, Performance and emissions.

\section{INTRODUCTION}

Energy is essential input for economics growth, social development, human welfare and improving the quality of life. The diesel engine dominate the field of commercial transportation and agricultural machinery due to its ease of operation and higher fuel efficiency. The consumption of diesel oil is several times higher than that of petrol. Indiscriminate extraction and lavish consumption of fossil fuels have led to reduction in underground-based carbon resources. It received attention only recently when it was conclusively realized that petroleum fuels are dwindling fast and environment - friendly renewable substitutes must be identified. (1). Due to the shortage of petroleum products and its increasing cost, efforts are on to develop alternative fuels especially, to the diesel oil for fully or partial replacement. It has been found that the vegeTable- oils are promising fuels because their properties are similar to that of diesel and are produced easily and renewably from the crops. The fuels of bio-origin can provide a feasible solution to this world wide petroleum crisis. $\mathrm{CO}_{2}$ emissions have risen over the last two decades, reaching an atmospheric content of 360ppm, estimating the world. $\mathrm{CO}_{2}$ emissions at about 26 billion metric ton per year, 80 percent of which comes from the combustion of fossil combustibles such as coal, petroleum and natural gas. (2) (3). Thus it is essential that low emission alternate fuels must be developed for use in diesel engine. An accepTable- alternative fuel for engines has to fulfill the environmental and energy security needs without sacrificing operating performance. (4) The problem of corrosion of various engine parts utilizing alcohol as fuel is also solved by way of tranesterificarion. (5)
VegeTable- oils have comparable energy density, cetane number, heat of vaporization and stoichiometric airfuel ratio with that of the diesel fuel. A catalyst is used to make possible the reaction rate and yield because the reaction is reversible, excess alcohol is used to complete the reaction(6). None other than Rudolph Diesel, the father of diesel engine, demonstrated the first use of vegeTableoil in compression ignition engine. Some reasearches have worked with feedstock having higher acid value using alternative transesterification process(7) (8). The enormous growth of world population, increased technical development, and standard of living in the industrial nations has led to this intricate situation in the field of energy supply and demand Presently, considerable research has been undertaken to understand the performance characteristics of biodiesel- fueled engine as well as the biodiesel production technology $(9)(10)$.

The researchers and development activities in several countries on this subject have been mostly on sunflowers, saffola, soybean, rapeseed, pea nut and a host of others. Most of these oils are edible in Indian context. Thus the emphasis of the present work is to experimentally evaluate the possibilities of using biodiesel developed from one of the number of non-edible oil seeds available in India. Bio diesel can be produced from non-edible oil seeds like Jatropha, Karanja, and can be grown in the waste lands of the country. Jatropha oil have a great potential to produce biodiesel for diesel engine application(11) (12). The production and utilization of Jatropha oils are low at present, because of their limited end usage, utilization of these oils / biodiesel as fuels in internal combustion engines are not only reducing the petroleum usage, but 
also improve the rural economy. Efforts are made here to produce biodiesel from typical Jatropha oil and to use it as the fuel in diesel engines. The European commmission proposed a 12 percent market share for biofuels by the year 2020. (13)

The use of vegeTable- oils for engine fuels may seem insignificant today, but such oils may become in course of time as important as petroleum and the coal tar products of the present times(14). Due to higher viscosity, the straight vegeTable- oil cause poor fuel atomization, incomplete combustion and carbon deposition on the injector and valve seats resulting serious engine fouling. It has been reported in literature that out of different methods available for reducing the viscosity. Transesterification is one of the most reliable and commonly used techniques to produce biodiesel from oil seeds. Alkali catalyzed transesterification is faster than acid catalyzed transertorification and is most often used commmercially(15),(16). This paper highlights a part of the experimental activities carried out in Sathyabama University on production of biodiesel from Jatropha oil having high acid value in a pilot plant and its subsequent utilization in a single cylinder diesel engine.

The best way to use vegeTable- oil as fuel is to convert it in to biodiesel. Biodiesel in the name of a clean burning mono-alkyl ester-based oxygenated fuel made from natural, renewable sources such as new / used vegeTableoils and animal fats. The resulting biodiesel is quite similar to conventionaldiesel in its main characteristics. Bio-diesel contains no petroleum products, but it is compatible with conventional diesel and can be blended in any proportion with mineral diesel to create a sTable- biodiesel blend. The level of blending with petroleum diesel is referred as Bxx, where $m x x$ indicates the amount of biodiesel in the blend (ie. Bio blend is $10 \%$ biodiesel and $90 \%$ biodiesel). It can be used in $\mathrm{Cl}$ engine with no major modification in the engine hardware.

\section{MATERIALS \& METHODS}

\section{A. BIODIESELPRODUCTION PROCEDURE:}

Esterification is a very effective way to modify the vegeTable- oil structure and reduce its viscosity. The formation of methyl esters by tranesterification of vegeTable- oils require three moles of alcohol stoichiometrically. However, transesterification is an equilibrium reaction in which excess alcohol is required to drive the reaction close to completion. Studies have been carried out in different oils such as soybean, sunflower, rape, coconut,palm, rubber seed and cotton seed(17).A round bottom flask of $500 \mathrm{~cm}^{3}$ is used as laboratory scale reactor for the present analysis. Jatropha oil in the flask was heated on a hot plate having magnetic stirrer arrangement. The mixture was stirred at the same speed for all test runs. The temperature maintained for the whole esterification process is between $50^{\circ} \mathrm{C}$ and $60^{\circ} \mathrm{C}$. For the stoichiometric transesterification, $3 \mathrm{~mol}$ of alcohol are required for each mole of the oil. A molar ratio of 9:1 and $0.5 \%$ by weight of sodium hydroxide is found to give the maximum ester yield. After the reaction is completed, the products are allowed to separate into two layers. The lower layer contains impurities and glycerol. This top layer (ester) is separated and purified using distilled water. Hot distilled water ( $10 \%$ by volume) is sprayed over the ester and stirred gently and allowed to settle in the separating funnel. The lower layer is discarded and upper layer (purified biodiesel) is separated. The process of transesterification brings about drastic change in viscosity of vegeTable- oil. The biodiesel resulted in a clear ambient - light yellow liquid with a viscosity similar to petro-diesel.

\section{B.BIODIESEL CHARACTERIZATION:}

The molar ratio of methanol to oil (triglyceride) which is sufficient to give $85 \%$ yield of ester. The reaction was completed up to $85 \%$ in $90 \mathrm{~min}$ and the reaction was carried out for $4 \mathrm{hr}$ to achieve complete reaction. The physicochemical properties of the Jatropha oil, neat petro diesel, neat biodiesel (B100) and its blend of $20 \%$ at each step were evaluated as per the ASTM standard methods and the results are in accordance with ASTM. The fuel properties of Jatropha oil methyl ester and its different blends with diesel are shown in Table- 1. It is observed that the chemical characteristics of the Jatropha oil methyl ester were found to be in the close range to engine requirement.

Properties of Jatropha oil Methyl Ester (Bio diesel) in comparison with diesel and blends.

Table 1

\begin{tabular}{|llllll|}
\hline Fuel Blends & Viscosity (cst) & $\begin{array}{l}\text { CalorificValue } \\
(\mathrm{MJ} / \mathrm{Kg})\end{array}$ & FlashPoint $\left({ }^{\circ} \mathrm{C}\right)$ & $\begin{array}{l}\text { Cloud } \\
\left({ }^{\circ} \mathrm{C}\right)\end{array}$ & $\begin{array}{l}\text { Point } \\
\text { Pour Point } \\
\left({ }^{\circ} \mathrm{C}\right)\end{array}$ \\
\hline HSD & 2.88 & 44.12 & 75 & 6.5 & -3 \\
B20 & 2.97 & 43.95 & 85 & 7.7 & 2.7 \\
B40 & 3.25 & 42.51 & 92 & 8.4 & 2.7 \\
B60 & 3.52 & 40.91 & 97 & 10.8 & 3.3 \\
B80 & 3.70 & 39.19 & 110 & 10.9 & 3.7 \\
B100 & 4.91 & 38.16 & 138 & 13.1 & 4.4 \\
\hline
\end{tabular}


The important properties of Jatropha seed oil methyl esters are found out and compared with that of the others ester and diesel(18)- (20) (Table- 2). It can be seen that the properties of Jatropha seed oil methyl esters are quite comparable to that of other esters. The comparison shows that the methyl ester has relatively closer fuel properties to diesel than that of original Jatropha seed oil. The viscosity was substantially got reduced from a value of 6.6 to
$5.81 \mathrm{~mm}^{2} / \mathrm{sec}$ (approximately one eleventh of initial value). The calorific value of methyl ester is lower than that of diesel because of its oxygen content. The flash point of the ester is higher than that of diesel.A small percentage of biodiesel addition with diesel can definitely improve the flash point of the resultant mixture. Hence, this fuel is safer to store and transport compared to that of pure diesel.

Table 2. Properties of Jatopha seed oil methyl esters in Comparison with other esters and diesel.

\begin{tabular}{|c|c|c|c|c|c|c|c|}
\hline Property & Diesel & $\begin{array}{c}\text { Jatropha } \\
\text { seed oil } \\
\text { methyl } \\
\text { ester }\end{array}$ & $\begin{array}{c}\text { Rape } \\
\text { seed oil } \\
\text { methyl } \\
\text { ester }\end{array}$ & $\begin{array}{c}\text { Soy bean } \\
\text { oil methyl } \\
\text { ester }\end{array}$ & $\begin{array}{c}\text { Sunflower } \\
\text { oil methyl } \\
\text { ester }\end{array}$ & $\begin{array}{c}\text { Rubber } \\
\text { oil methyl } \\
\text { ester }\end{array}$ & $\begin{array}{l}\text { Cotton seed } \\
\text { oil methyl } \\
\text { ester }\end{array}$ \\
\hline Specific gravity & 0.836 & 0.872 & 0.872 & 0.888 & 0.872 & 0.872 & 0.873 \\
\hline Colorific value & 42.6 & 40.56 & 36.4 & 39.82 & 40.51 & 36.20 & 40.33 \\
\hline $\begin{array}{l}\text { Viscosity }\left(\mathrm{mm}^{2} / \mathrm{sec}\right. \\
\text { at } 40^{\circ} \mathrm{C}\end{array}$ & 3.7 & 4 & 5.83 & 4.09 & 4.4 & 5.80 & 5 \\
\hline Flash Point $\left({ }^{\circ} \mathrm{C}\right)$ & 45 & 70 & 130 & 72 & 83 & 132 & 70 \\
\hline Diesel Index & 45 & 46.9 & 45 & 50.2 & 46.2 & 45 & 51.3 \\
\hline Cloud Point $\left({ }^{\circ} \mathrm{C}\right)$ & -1 & 1.0 & 5 & -2 & 1.0 & 5 & -3 \\
\hline Pour Point $\left({ }^{\circ} \mathrm{C}\right)$ & -16 & -13 & -9 & -3 & -8 & -9 & -15 \\
\hline
\end{tabular}

\section{RESULTS \& DISCUSSION}

ENGINE PERFORMANCE STUDY:- Short-term engine performance tests were carried out on a small-size water-cooled direct injection diesel engine with neat diesel oil, neat biodiesel (B 100) and its blend of $20 \%$ at each step. A four stroke, diesel injection, naturally aspirated single cylinder diesel engine is employed for the present study. The tests are conducted at the rated speed of 1500 $\mathrm{pm}$ at various loads. The experimental data generated are documented and presented here using appropriate graphs.

Engine systems was equipped with several experimental subsystems and was instrumented at the appropriate location (Fig 1) to evaluate the performance parameters such as brake specific fuel consumption (BSFC), brake specific energy consumption (BSEC), brake mean effective pressure (BMEP), brake thermal efficiency(BTE), and volumetric efficiency(VE). The dynamometer used to load the engine comprised a shunt wound $\mathrm{AC}$ generator and load bank pressure in the inlet monifold was measured by a normal U- tube manometer. The fuel system was modified by adding an additional filter and three way, hand operated, two position directional control valve which allowed rapid switching between the diesel fuel used as a standard and the test fuels. Fuel was fed to the injector pump under gravity and the volumetric flow rate was measured by the use of a $50 \mathrm{~cm}^{3}$ - graduated burette and stop watch.

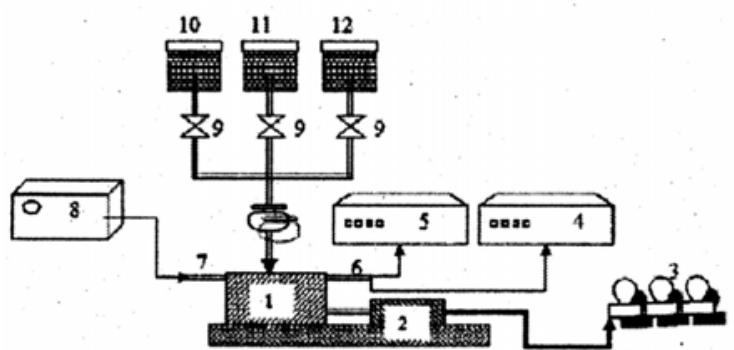

Fig.1 Engine System

1.Single cylinder 4- strooke diesel engine

2. Alternator

3. Lamp load

4. Gas Analayzer

5. Smokemeter6. Exhaust manifold

7. Intake manifold

8. Air drum

9. Control valve

10. Fuel Tank for neat diesel

11. Fuel Tank for blends of diesel and biodiesel

12. Fuel Tank for neat biodiesel (B100)

\section{BRAKE THERMAL EFFICIENCY:}

Thermal efficiency purely depends on engine design, type of fuel used and area of application. VegeTable- oil (Unrefined Jatropha oil) based fuel contains oxygen (10$12 \%)$, which causes better combustion in case of esters compared to diesel. The variation of brake thermal efficiency with respect to load for different fuels considered for the present analysis is presented in Fig 2. In all cases, 
brake thermal efficiency has the tendency to increase with increase in applied load. This is due to the reduction in heat loss and increase in power developed with increase in load. The maximum brake thermal efficiency obtained is about $28 \%$ for $\mathrm{B} 20$, which is quite higher than that of diesel $(25 \%)$ and for B50, B75 and B100 are respectively, 25, 25 and $24 \%$.

The lower brake thermal efficeincy obtained for B100 could be due to the reduction in calorific value and increase in fuel consumption as compared to B20. The mixing of biodiesel in diesel oil yields, in general, good thermal efficiency curves.

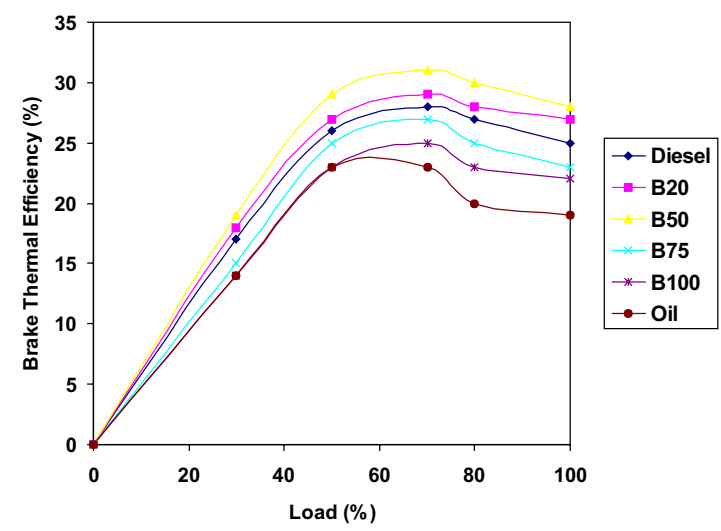

Fig. 2. Brake thermal efficiency of Jatropha seed oil, diesel and biodiesel with respect to load.

\section{SPECIFIC FUEL CONSUMPTION :}

The fuel consumption for biodiesel were comparatively higher than that of diesel fuel due to high specific gravity which is shown in Fig 3 for different fuels. For all fuels tested, brake specific fuel consumption is found to decrease with increase in the load. This is due to the higher percentage increase in brake power with load as compared to the increase in fuel consumption.

At maximum load condition, the specific fuel consumption of $100 \%$ biodiesel is more than $12 \%$ than that of diesel. Hence, the specific fuel consumption of the higher percentage of biodiesel in blends increases as compared to that of diesel. The SFC of Jatropha oil is higher than that of diesel for all loads. Specific Fuel Consumption of Jatropha seed oil, diesel and biodiesel with respect to load is shown in Fig 3

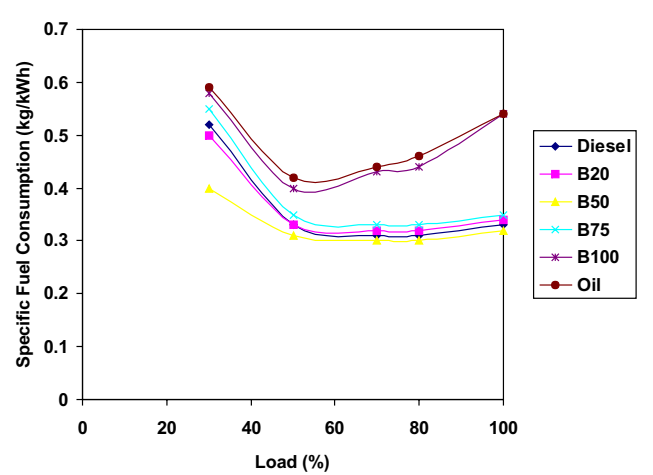

Fig. 3. Specific Fuel Consumption of Jatropha seed oil, diesel and biodiesel with respect to load

\section{CARBON MONOXIDE EMISSION:}

Carbon emission depends upon combustion efficiency and carbon content of the fuel, which during combustion undergoes a series of oxidation and reduction reactions. Carbon content of fuel is oxidized with available in the air to $\mathrm{CO}$ and then to $\mathrm{CO}_{2}$. Carbon, which is not converted to $\mathrm{CO}_{2}$, will come back as $\mathrm{CO}$ in the exhaust. For all biodiesel, $\mathrm{CO}$ emissisons is lower than that of diesel $(0.34 \% \mathrm{~V} / \mathrm{V})$. The fuels are producing low amount of carbon monoxide emission at lighter load levels and are giving more emissions at higher loading conditions. The carbon monoxide emissions are found to be increasing with increase in load. This is typical with all IC engines since the air-fuel ratio decreases with increase in load. It is interesting to note that, the engine emits more $\mathrm{CO}$ using diesel as compared to that of biodiesel blends under all loading conditions. Biodiesel itself has about $11 \%$ oxygen content in it. This helps for complete combustion. Hence emission level decreases with increasing biodiesel percentage in the fuel. The higher viscosity and poor atomization tendency of 100\% Jatropha oil leads to poor combustion and high CO emission. Carbonmonoxide emission of Jatropha oil, diesel and biodiesel with respect to load is shown in Fig 4

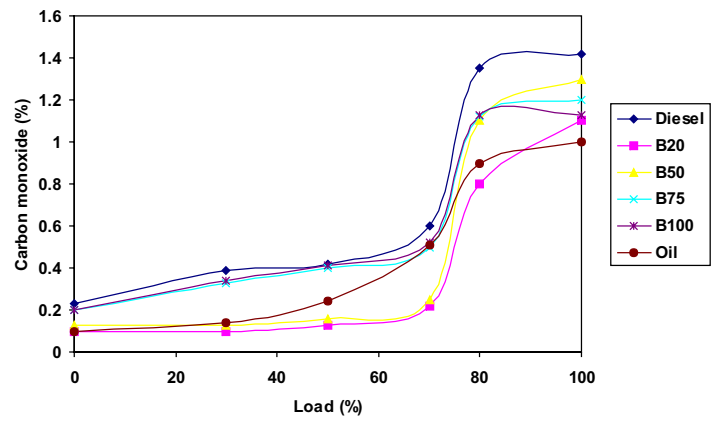

Fig. 4. Carbon monoxide emission of Jatropha oil, diesel and biodiesel with respect to load. 


\section{CARBON DIOXIDE EMISSION:}

For good combustion, all carbon must come as $\mathrm{CO}_{2}$ in the exhaust but the situation is different. All carbon in the fuel cannot be converted to $\mathrm{CO}_{2}$. But in case of biodiesel, addditional $\mathrm{O}_{2}$ present helps combustion compared to diesel. The $\mathrm{CO}_{2}$ emission increase with increase in load. The lower percentage of biodiesel blends emits very low amount of $\mathrm{CO}_{2}$ in comparison with diesel. Using higher concentration biodiesel blends as the fuel, $\mathrm{CO}_{2}$ emission is found to increase, but B20 emits very low level of $\mathrm{CO}_{2}$ emissions. The $\mathrm{CO}_{2}$ emissions using Jatropha oil as fuel is lower because of the incomplete combustion. Carbon dioxide emission of Jatropha oil, diesel and biodiesel with respect to load is shown in Fig 5

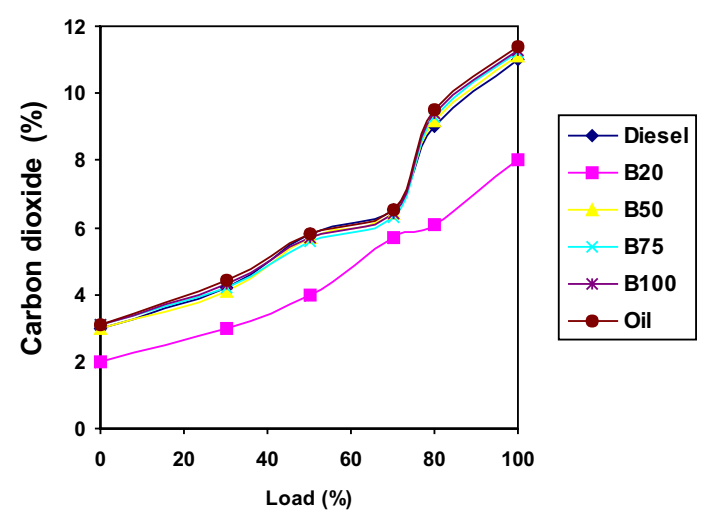

Fig. 5. Carbon dioxide emission of Jatropha oil, diesel and biodiesel with respect to load.

\section{SMOKE DENISTY:}

Somke denisty for biodiesel blend of different fuels is noticed to be generally lower than that of the diesel oil . B20 blends gave smoke density of $28 \%$ as compared to $45 \%$ in the case of diesel. Higher thermal efficiency indicates better and complete combustion of fuel. So, lower smoke density values are achieved with biodiesel blends as compared to that of the diesel. Smoke density of Jatropha seed oil, diesel and biodiesel with respect to load is shown in Fig 6

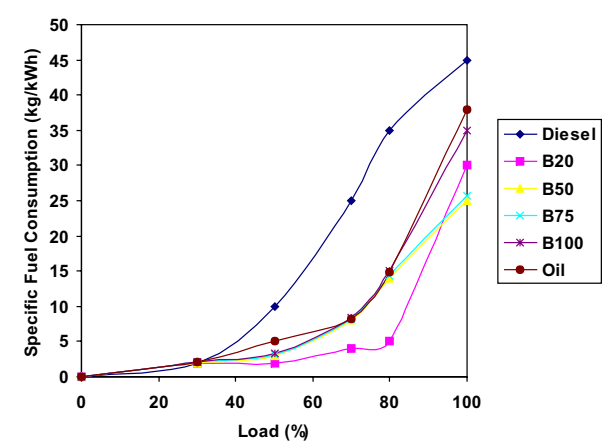

Fig. 6. Smoke density of Jatropha seed oil, diesel and biodiesel with respect to

\section{EXHAUST GAS TEMPERATURE:}

Biodiesel also contains some amount of oxygen molecules in the ester form. It is also taking part in the combustion. Upto B20 the exhaust gas temperature is lower. When biodiesel concentration is increased, the exhaust gas temperature increases by a small value. While using 100\% Jatropha oil, higher exhaust temperature is attained, which is indicating more energy loss in this case. The exhaust gas temperature increases with increase in load for all tested fuels. With increase in the value of exhaust gas temperature $\mathrm{NO}_{x}$ emission also increases. That is, biodiesel fueled engines has the potential to emit more $\mathrm{NO}_{x}$ as compared to that of diesel fueled engines. Exhaust gas temperature of Jatropha seed oil, diesel and biodiesel with respect to load is shown in Fig 7

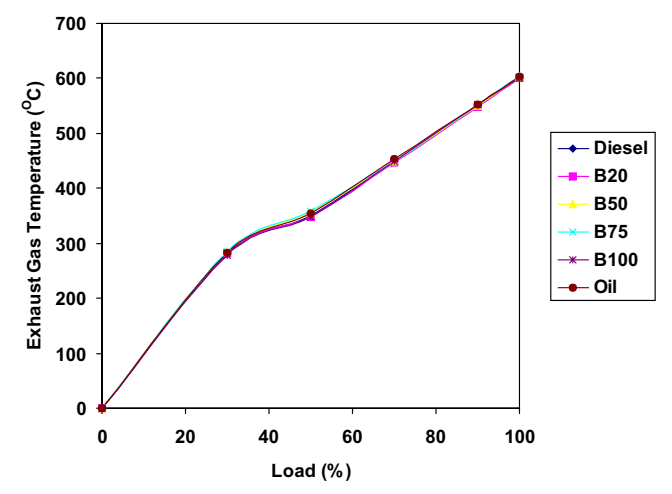

Fig. 7. Exhaust gas temperature of Jatropha seed oil, diesel and biodiesel with respect to the load

\section{CONCLUSION}

Based on the exhaustive engine tests, it can be concluded that Jatropha based biodiesel can be adopted as an alternative fuel for the existing conventional diesel engines without any major hardware modifications in the system. The viscosity of vegeTable- oil reduces substantially after transesterification. Viscosity and Density of methyl esters of Jatropha oil are found to be very close to that of diesel. The important properties of biodiesel produced from Jatropha oil are quite close to that of diesel. The flash point of biodiesel is found to be more than that of diesel. The calorific value of biodiesel is found to be slightly lower than that of diesel. The various blends of biodiesel-diesel are used as fuel in compression Ignition engines and its performance emission characteristics are analyzed. The lower concentrations of biodiesel blends found to improve the thermal efficiency. B20 biodiesel blend gives good improvement in the brake thermal efficiency of diesel engine by about 3\% at the rated load conditions. Also, reduced emission and brake specific fuel cosumption is found out while using B2O. 
The exhaust gas temperature increased as a function of concentration of biodiesel in the blend, since the $\mathrm{NO}_{x}$ emission formation is a highly temperature dependant phenomenon, with increase in biodiesel blends, $\mathrm{NO}_{x}$ emission is also expected to increase.

The present experimental results supports that methyl esters of Jatropha seed oil can be succesfully used in existing diesel engines without any modifications. Use of the biodiesel as partial diesel substitute can boost the farm economy, reduce uncertainty of fuel availability and make farmers more self reliant. It was conclusively proved that excess oxygen content of biodiesel played a key role in engine performance. The perfomance of biodiesel-diesel fueled engine was marginally better than the diesel- fueled engine in terms of thermal efficiency, brake specific energy consumption, smoke opacity, and exhaust emissions including $\mathrm{NO}_{x}$ emission for entire range of operations.

\section{REFERENCES}

[1] AK Agarwal, L M Das, 2000, Biodiesel development and characterization for use as a fuel in compression ignition engines, Am Soc Mech Eng J Eng, Gas Turbines Power 123, pp.440-447.

[2] TTuer S, D Uzun \& TTure IE,1997, The potential use of sweet sorghum as a non- polluting source of energy, Energy, 22, pp. 17-19.

[3] L. J.A Topez Sastire, L Guijosa \& M Sanz,1998, VegeTable- oils as combustibler (Advanced combustion Research for VegeTable- oils,orleans, France).

[4] "Biodiesel", 199 P.Manjula.et al: 9, National Biodiesel Board Report, Jefferson city, MO 65110-4898.

[5] K.W Scholl, and S.C Soreson, 1993, "Combustion of Soybean oil Methyl Ester in a Direct Injection Diesel Engine,"SAE paper 930934, pp.1450- 1461.

[6] Ma F. M.A. Hanna, 1999, Biodiesel production : a review. Bioresour Technology;70, pp.1-15.

[7] AS Ramadass, S Jayaraj, C Muraleedharan, 2005,diesel production from high FFA VegeTableoil, Fuel 84, pp.335-40.
[8] SV Ghadge, H Rahema, 2005,Biodiesel production from Mahua (Madhumica indica) oil having high free fatty acids, Biomass Bioenergy 28, pp.601-605.

[9] A Recep, C Selim, SY Huseyin, 2001 The potentinal of using vegeTable- oil fuels as fuel for diesel engines, Energy Convers Manage; , pp.42.

[10] NDS Fernando, SP Antonio, RT Jorge, 2003Technical feasibility assessment of oleic sunflower methyl ester utilization in diesel bus engines Energy convers Manage;44

[11] A.A Senatore, 2000, Comparitive analysis of combustion process in D.I. diesel engine fueled with bio- diesel and diesel fuel, SAE 2000-01-0691;

[12] CL Peterson, $\mathrm{H}$ Tool, 1998 Carbon cycle for rapeseed oil biodiesel fuels, BiomassBioenergy; 14 .

[13] W Korbitz, 1999, "Biodiesel Production in Europe and North America, an Encouraging Prospect, " Renewable Energy, 16, pp.1078-1083.

[14] T Krawezyk, (1996) "Biodiesel alternative fuel makes in roads but hurdles remain," Inform, 7 pp. 801-814.

[15] LA Nelson, TA Fogila \& WN Marmer, 1996,Lipasecatalyzed production of biodiesel, JONC,73, pp.1191-1195.

[16] MAFanguri \& MA Hanna, 1993,Biodeisel production: A review, Biores. Kyle W.S \& Spencer C S, Combustion of soybean oil methyl ester in a direct injection diesel engine, SAE-930-934 , pp.555-567.

[17] OE IKWuagawu, IC Ononogo bo, OU Njoku, 2002Production of biodiesel using rubber seed oil. Ind crops prod; 12 .

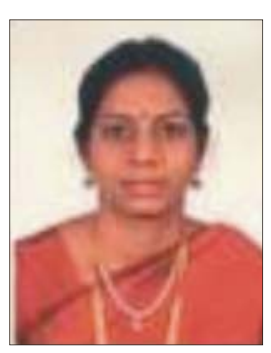

Mrs. Manjula.P is presently working as a Senior Lecturer, Department of Chemical Engineering, Sathyabama University, Chennai. She has presented papers in 9 National Conferences and 5 International Conferences. 